\title{
Reply to the Letter to the Editor on the article "Soft tissue profile changes after mandibular setback surgery" (Dent Med Probl 2016, 53, 4, 447-453)
}

\section{Odpowiedź na list do Redakcji dotyczący pracy pt. „Zmiana profilu tkanek miękkich po jednoszczękowych zabiegach korekcji progenii" (Dent Med Probl 2016, 53, 4, 447-453)}

\author{
Katarzyna Bogusiak', Marek Kociński², Adam Łutkowski , Andrzej Materka², \\ Aneta Neskoromna-Jędrzejczak ${ }^{1}$ \\ 1 Department of Craniomaxillofacial and Oncological Surgery, Medical University of Lodz, Łódź, Poland \\ ${ }^{2}$ Institute of Electronics, Department of Medical Electronics, Technical University of Lodz, Łódź, Poland
}

Address for correspondence Katarzyna Bogusiak

E-mail: katarzyna.bogusiak@gmail.com

DOI

$10.17219 / \mathrm{dmp} / 69933$

Copyright

(c) 2017 by Wroclaw Medical University@ 2017 by Wroclaw Medical University and Polish Dental Society This is an article distributed under the terms of the Creative Commons Attribution Non-Commercial License (http://creativecommons.org/licenses/by-nc-nd/4.0/)
Key words: soft tissue profile, cephalometry, bilateral sagittal split osteostomy (BSSO), extraoral vertical ramus osteotomy (EVRO)

Słowa kluczowe: profil tkanek miękkich, cefalometria, obustronna strzałkowa osteotomia gałęzi żuchwy, pionowa osteotomia gałęzi żuchwy z dostępu zewnątrzustnego

The evaluation of soft tissues is an integral part of orthodontic and maxillofacial diagnosis and treatment planning of patients with orthognathic defects. ${ }^{1}$ The forehead, nose, upper and lower lip, and chin are the anatomical structures that create facial profile. Both corrective surgery and orthodontic treatment affect the patients' appearance and facial contours. Many authors emphasized the significance of soft tissue analysis in the proper evaluation of skeletal discrepancy, which could be altered by individual differences in soft tissue thickness. ${ }^{2-4}$ Different cephalometric soft tissue analyses have been developed for clinical and experimental purposes to quantitatively and more reliably evaluate the facial morphology. ${ }^{5-12}$ Soft tissue assessment on lateral cephalograms is not as straightforward and easy to reproduce as the analysis of hard tissue structures of the face. Such quantification requires the curved surfaces of patients' profile to be reduced to distances, angles and ratios, which makes such a procedure less precise. ${ }^{13}$ Soft tissue profile analyses are variable also because their measurements involve the construction of straight lines of facial contours between anatomic landmarks located along the soft tissue profile or by lines tangent to the curved surfaces. ${ }^{13}$ These lines form the angles and distances of cephalometric methods. There are also 3D cephalometric methods that include soft tissue landmarks, angles and distances. ${ }^{14-18}$ McNamara's analysis is well-established and is believed to be a very practical cephalometric tool. Its norms have been studied in various populations due to their optimal efficacy. ${ }^{19,20}$ This method, through the measurement of angles, describes the thickness of soft tissue facial profile.

Data on the shift of the facial profile and on hard-to-soft tissue ratio after surgical corrective procedures affects treatment planning and is of a great im- 
portance in predicting the aesthetic treatment outcome. Orthognathic surgery affects lips positions. Ayoub indicated that the response of soft tissues of the upper lip region to anterior maxillary osteotomy is related to their thickness - the thicker they are, the lower is the postoperative change. ${ }^{21}$ After mandibular setback surgeries, the position of the upper and lower lips is also changed. The changes in the upper lip position after mandibular surgery were explained by the contraction of the orbicularis oris muscle and soft tissue traction. ${ }^{22}$ Some authors hypothesized that the thickness and posture of presurgical soft tissue may affect the post-treatment position of the upper lip. ${ }^{23}$ The relation of incisors before the surgery should also be considered. Several factors may contribute to the postoperative position of the lower lip. It should be emphasized that lower lip position is determined by upper and lower incisors, perioral muscles, their thickness and tonicity. ${ }^{24-26}$ In our article, in the analyzed groups of patients (after EVRO and BSSO), men and women did not differ significantly in terms of presurgical soft tissue profile assessed with Hwang, Kim and McNamara analysis. The measurements were performed with an anatomical-based method. ${ }^{27}$

We believe that more prospective studies are still needed that would stratify such confounding factors as the magnitude of movement, method of osteosynthesis, sex, age, race, quality and quantity of soft tissues with sufficient sample sizes.

\section{References}

1. McNamara JA Jr, Brust EW, Riolo ML. Soft tissue evaluation of individuals with an ideal occlusion and a well-balanced face. In: Esthetics and the treatment of facial form. Center for Human Growth and Development, The University of Michigan, Ann Arbor, 1993 (Monograph 28, Craniofacial Growth Series).

2. Subtelny JD. A longitudinal study of soft tissue facial structures and their profile characteristics, defined in relation to underlying skeletal structures. Am J Orthod. 1958;45:481-507.

3. Burstone $\mathrm{CJ}$. Integumental contour and extension patterns. Angle Orthod. 1959;29:93-104.

4. Bowker WD, Meredith HV. A metric analysis of the facial profile. Angle Orthod. 1959;29:149-160.

5. Merrifield LL. The profile line as an aid in critically evaluating facial esthetics. Am J Orthod. 1966;52:804-822.

6. Ricketts RM. Esthetics, environment, and the law of lip relation. $A m$ J Orthod. 1968;54:272-289.

7. Burstone CJ, James RB, Legan H, Murphy GA, Norton LA. Cephalometrics for orthognathic surgery. J Oral Surg. 1978;36:269-277.

8. Holdaway RA. A soft tissue cephalometric analysis and its use in orthodontic treatment planning. Part I. Am J Orthod. 1983;84:1-28.
9. Holdaway RA. A soft tissue cephalometric analysis and its use in orthodontic treatment planning. Part II. Am J Orthod. 1984;85:279-293.

10. Williams S. A short guide on cephalometry in orthodontics. Polorto. Częstochowa 1998 [in Polish].

11. Neger M. A quantitative method for the evaluation of the soft-tissue facial profile. Am J Orthod. 1959;45:738-751.

12. Lusterman EA. The esthetics of the occidental face: A study of dentofacial morphology based upon anthropologic criteria. Am J Orthod. 1963;49:826-850.

13. Hwang HS, Kim WS, McNamara JA Jr. A comparative study of two methods of quantifying the soft tissue profile. Angle Orthod. 2000; 70:200-207.

14. Olszewski R, Villamil MB, Trevisan DG, et al. Towards an integrated system for planning and assisting maxillofacial orthognathic surgery. Comput Meth Prog Bio. 2008;9:13-21.

15. Shimomatsu K, Nozoe E, Ishihata K, Okawachi T, Nakamura N. Three-dimensional analyses of facial soft tissue configuration of Japanese females with jaw deformity - a trial of polygonal view of facial soft tissue deformity in orthognathic patients. J Craniomaxillofac Surg. 2012;40:559-567.

16. Swennen GR, Schutyser F, Barth EL, De Groeve P, De Mey A. A new method of 3-D cephalometry Part I: the anatomic Cartesian 3-D reference system. J Craniofac Surg. 2006;17:314-325.

17. Baysal A, Sahan AO, Ozturk MA, Uysal T. Reproducibility and reliability of three-dimensional soft tissue landmark identification using three-dimensional stereophotogrammetry. Angle Orthod. 2016;86:1004-1009.

18. Treil J, Braga J, Aït Ameur A. 3D representation of skull and soft tissues. Usefulness in orthodontic and orthognathic surgery. J Radiol. 2009;90:634-641.

19. Nouri M, Hamidiaval S, Akbarzadeh Baghban A, Basafa M, Fahim M. Efficacy of a newly designed cephalometric analysis software for McNamara analysis in comparison with Dolphin software. J Dent. (Tehran) 2015;12:60-69.

20. Hwang HS, Kim WS, McNamara JA Jr. Ethnic differences in the soft tissue profile of Korean and European-American adults with normal occlusions and well-balanced faces. Angle Orthod. 2002;72:72-80.

21. Ayoub AF, Yahya AM. Soft tissue response to anterior maxillary osteotomy. Int J Adult Orthod Orthognath Surg. 1991;6:183-190.

22. Jung YJ, Kim MJ, Baek SH. Hard and soft tissue changes after correction of mandibular prognathism and facial asymmetry by mandibular setback surgery: three-dimensional analysis using computerized tomography. Oral Surg Oral Med Oral Pathol Oral Radiol Endod. 2009;107:763-771.

23. Gjørup H, Athanasiou AE. Soft-tissue and dentoskeletal profile changes associated with mandibular setback osteotomy. Am J Orthod Dentofacial Orthop. 1991;100:312-323.

24. Chunmaneechote P, Friede H. Mandibular setback osteotomy: facial soft tissue behavior and possibility to improve the accuracy of the soft tissue profile prediction with the use of a computerized cephalometric program: Quick Ceph Image Pro: v. 2.5. Clin Orthod Res. 1999;2:85-98.

25. Solow B, Tallgren A. Natural head position in standing subjects. Acta Odontol Scand. 1971;29:591-607.

26. Momeni Danaei SH, Zamiri B, Khajeh F, Torkan S, Ghodsi Bushehri S. Comparative study of facial soft tissue profile changes following bilateral sagittal split and subcondylar osteotomies in patients with mandibular prognathism. J Dent Sch. 2013; 30:248-255.

27. Bogusiak K, Kociński M, Łutkowski A, Materka A, Neskoromna-Jędrzejczak A. Soft tissue profile changes after mandibular setback surgery. Dent Med Probl. 2016;53:447-453. 